Invited Commentary

\title{
No More Settler Tears, No More Humanitarian Consternation: Recognizing our Racist History and Present NOW!
}

\author{
Catherine Larocque, RN, MScN, Thomas Foth, RN, PhD, and Wendy Gifford, RN, PhD \\ School of Nursing, University of Ottawa.
}

Cite as: Larocque, C., Foth, T. \& Gifford, W. (2021). No more settler tears, no more humanitarian consternation: Recognizing our racist history and present NOW! Witness: The Canadian Journal of Critical Nursing Discourse, Vol 3(1), pp 7-10 https://doi.org/ 10.25071/2291-5796.107

\section{Introduction}

The recent 'discoveries' of the remains of the 215 murdered children at the Kamloops residential school, and the 751 murdered children at the Marieval residential school in Saskatchewan, has, for many, brought to the forefront the systematic and willful negation of Canada's genocidal settler colonial history that continues today. We write as two white settler colonialists with European descent (Thomas and Wendy) and one non-status Indigenous person from the Oneida Nation (Catherine) in what is today called Canada. What we find most striking is the outrage and outpouring of white tears in the aftermath of these 'discoveries'; this outrage is both perplexing and offensive. It is perplexing as these are not 'discoveries' at all. Indigenous people have always known about these massacres, about the children who would go out to the field at night and never return; about the bodies that were never returned to their families; about the children who were told their parents never wanted to see them again and were forcibly placed into settlers' homes; children who were tortured and molested to 'beat the Indian out of the child'; the countless suicides in bathrooms; and the forced abortions and sterilizations of girls who were raped by priests and clergy, to name only a few of the atrocities
(Berrera, 2021; Mosby, 2013). Indigenous people have been screaming and pleading for decades to be heard, to be listened to, and to be believed (Kestler-D'Amour, 2021). Countless oral histories and traditional historical accounts, reports, declarations r(e.g., United Nations Declaration on the Rights of Indigenous Peoples), commissions (e.g., Truth and Reconciliation Commission of Canada), court battles, etc. have sought to bring these stories to the forefront and yet, we ask, where was the outrage then?

Governments, and the majority of Canadian settler society, have disregarded and ignored these stories and voices and continue to blindly benefit from the privileges of these racial injustices. Only now, when faced with the physical and material 'proof' of bones and skeletons can this reality of Canadian society no longer be ignored or denied. We emphasize that for colonialists and clergy these bones and skeletons were not even considered worthy enough to be returned to families or communities for respectful honouring and interment, and the perpetrators, both clergy and federal government, intentionally and systematically purged, hid, or destroyed the thousands of documents that would be considered 'evidence.' But the reactions of

Corresponding Author: Catherine Larocque, RN, BScN, MScN, PhD (student), University of Ottawa. 
governments, churches, and settler societies are moral lip service which does nothing to address the root causes and deeply entrenched violence against Indigenous people in our society. We emphatically exert that the outrage, tears, and humanitarian calls are colonial appropriation of Indigenous pain and trauma. The genocide of Indigenous people at the hands of colonizers is now only worthy of recognition as the material bones and skeletons can no longer be denied, and the voice of the colonizer is credited with recognizing these heinous atrocities, despite Indigenous people knowing and screaming about them for over a century. It is offensive that Indigenous pain, stories, and heritage are once again co-opted to suit the colonizer's needs. As poignantly stated by the member of parliament for Nunavut, Ms. Mumilaaq Qaqqaq, in her scathing farewell speech to the House of Commons,

I have heard so many pretty words like reconciliation, diversity, and inclusion $[\ldots]$ but let me be honest, brutally honest, nice words with no action hurt when they are uttered by those with power over the federal institution and refuse to take action. There is nothing, nothing, to take pride in, in the legacy this institution continues to not only maintain, but to build and fuel. People in power have choices and they consistently choose priorities that uphold systems of oppression [...]. Listen, believe us, and do something about it. (The Canadian Press, 2021)

\section{Necropolitics and Necropower}

Whereas politicians and clergy want to make us believe that the history of residential schools is behind us and that we live in a diversified and multicultural democracy, we contend that Kamloops is only the tip of the iceberg for uncovering Canada's genocidal history and demonstrates that we live in necropolitical societies, as described by Achille Mbembe (2019). Necropolitics is a form of sovereignty characteristic of liberal democratic colonial societies which produces entire populations and communities living in a space between life and death. Not quite living and not quite dead, necropower produces a form of living that is characterized by a constant struggle against death. These are the real conditions of Indigenous people in Canada living on reserves that do not have clean water, are systematically poisoned through resource exploitation, do not provide the minimal conditions necessary to survive, and have the constant threat of their children being taken away with the simple stroke of a colonizer's pen (National Inquiry into Missing and Murdered Indigenous Women and Girls, 2019). Necropower produces lives that are considered superfluous, worthless, and less than human; the deaths of these superfluous lives are not grievable because they were never considered livable in the first place (Butler, 2003, 2009). Therefore, as in the case of the Canadian residential schools, nobody felt they had an obligation to respond. Mbembe (2019) writes, "Necropolitical power proceeds by a sort of inversion between life and death, as if life was merely death's medium. It ever seeks to abolish the distinction between means and ends." (p. 38). In fact, necropower is the truth of our liberal democratic colonial societies and the foundational power that does everything to deny its own reality and disguise the necropolitical origins of our societies (Brown, 2014; Wolfe, 2006). Our necropolitical societies are built on an indifference for "objective signs of cruelty" (Mbembe, 2019, p. 38), and the deaths of those we consider enemies, or less than human, are not considered tragedies.

Racism is the driver of necropower, which must be understood as an organized form of destruction. The 'discovery' of these bones of Indigenous children in Kamloops demonstrates that massacres took place that reduced "lifeless bodies [...] to the status of simple skeletons" (Mbembe, 2019, p. 87). Although Mbembe draws particularly on the Rwandan genocide, his writings capture a deeper meaning of the discovery of these 'bones'; "Their [skeletons] morphology henceforth inscribes them in the register of undifferentiated generality: simple relics of an unburied pain; empty, meaningless corporealities; strange deposits plunged into cruel stupor" (p. 87). Mbembe continues, "the tension between, on the one hand, the petrification of the bones and their strange coolness, and, on the other, their stubborn will to 
mean, to signify something" (p. 87). As nurses and settlers, we must understand that the skeletons' will to exist and be 'discovered' signifies that our settler colonial societies have been metaphorically and literally built on the bones of Indigenous people, and this is our hidden truth. Our societies have never been peaceful and "civilized," but have always systematically and willfully produced superfluous, non-grievable lives.

\section{We, As Nurses}

Nurses have always been part of this necropower. One needs only to realize that many of the nuns working in residential schools were nurses, and, in the federal institutions, they were nurses tout court. It is enlightening to read the few remaining publicly accessible records of these children, because many of the notes in these records were made by nurses. Nurses were part of the barbaric medical and nutritional experiments enforced on the children in these schools without consent or knowledge from either the children or their parents. For example, nurses deliberately starved children of food and nutrients to create the Canada Food Guide and deliberately caused ear infections in children to test different 'therapies' and antibiotics (Mosby, 2013; Porter, 2013). Many children died from these experiments during their time at the schools, or shortly thereafter; in some schools, the mortality rate exceeded 50\% (Mosby, 2013). It is undeniable that nurses were an integral part of the colonial project in both residential schools and the so-called Indian hospitals. Thus, as nurses, we have a particular responsibility to confront our racist history and present. Our embeddedness in colonialism and colonial processes is foundational to the pervasive racism in healthcare and nursing (e.g., Joyce Echaquan and Brian Sinclair, see Lowrie \& Malone, 2020).

\section{References}

Berrera, J. (2021, June 13). Lost children. CBC News. https://newsinteractives.cbc.ca/longform/ka mloops-residential-school-children-dead
While we acknowledge efforts to raise awareness of these realities in nursing (e.g., Canadian Nurses Association, 2021), these efforts to date have been moral outrage at best and, in fact, highlight nursing's reticence to meaningfully engage with our past and present (Foth et al., 2018; Symenuk et al., 2020).

As Canadians, and particularly nurses, why did we not 'know' after the 1991 Commission on Aboriginal Peoples, after the United Nations' condemnation of Canada in 2007 under the Declaration of the Rights of Indigenous people, after the 2008 Truth and Reconciliation Commission of Canada and the 94 Calls to Action in 2015, and the Daniels ruling in 2014? We should have known, brought this knowledge to the forefront, and accepted that this is part of what nursing is. How many more bones must be dug up to continue appropriating Indigenous pain and trauma for settler ends? We are not shocked, we are not surprised, and we do not feel humanistic outrage. We are asking for political outrage. We are asking for Indigenous stories to be valued, heard, and believed. We do not need tears, we need action.

\section{Declaration of Conflicting Interests}

The authors declared no potential conflicts of interest with respect to the authorship and publication of this article.

\section{Funding}

The authors received no financial support for the authorship and publication of this article.

Brown, N. A. (2014). The logic of settler accumulation in a landscape of perpetual vanishing. Settler Colonial Studies, 4(1), 1-26. doi:10.1080/2201473X.2013.784236 
Butler, J. (2003). Violence, mourning, politics. Studies in Gender and Sexuality, 4(1), 937.

https://doi.org/10.1080/15240650409 $\underline{349213}$

Butler, J. (2009). Precarious life, grievable life. In Frames of war. When is life grievable? (pp. 1-32). Verso.

Canadian Nurses Association. (2021). Nursing declaration against anti-Indigenous racism in nursing and health care. https://cnaaiic.ca/-/media/cna/page-content/pdfen/1_0876-nursing-declaration-againstanti-indigenous-racism-in-nursing-andhealth-care-en-v3copy.pdf?la=en\&hash $=21 \mathrm{C} 8126 \mathrm{~F} 07 \mathrm{~F} 9 \mathrm{BF} 1$ 1F4E2DD729AE34258A2AB0EBE

Foth, T., Lange, J., \& Smith, K. (2018). Nursing history as philosophy - towards a critical history of nursing. Nursing Philosophy, 19(3), 1-11. https://doi.org/10.1111/nup.12210

Kestler-D'Amour, J. (2021, June 1). Canada: 'This one unmarked grave is what genocide looks like.' Al-Jazeera. https://www.aljazeera.com/news/2021/6/1/ canada-this-one-unmarked-grave-whatgenocide-looks-like

Lowrie, M., \& Malone, K. G. (2020, October 4). Joyce Echaquan's death highlights systemic racism in health care, experts say. CTV News. https://www.ctvnews.ca/health/joyceechaquan-s-death-highlights-systemicracism-in-health-care-experts-say1.5132146

Mbembe, A. (2019). Necropolitics (S. Corcoran, Trans.). Duke University Press.

Mosby, I. (2013). Administering colonial science: Nutrition research and human biomedical experimentation in Aboriginal communities and residential schools, 1942-1952. Histoire Sociale/Social History, 46(91), 145-172. https://doi.org/10.1353/his.2013.0015

National Inquiry into Missing and Murdered Indigenous Women and Girls. (2019).
Reclaiming power and place: The final report of the national inquiry into missing and murdered Indigenous women and girls (Vol. 1a). https://www.mmiwgffada.ca/final-report/

Porter, J. (2013, August 8). Ear experiments done on kids at Kenora residential school. CBC News. https://www.cbc.ca/news/canada/thunderbay/ear-experiments-done-on-kids-atkenora-residential-school-1.1343992

Symenuk, P. M., Tisdale, D., Bourque Bearskin, D. H., \& Munro, T. (2020). In search of the truth: Uncovering nursing's involvement in colonial harms and assimilative policies five years post Truth and Reconciliation Commission. Witness: The Canadian Journal of Critical Nursing Discourse, 2(1), 84-96. https://doi.org/10.25071/22915796.51

The Canadian Press. (2021, June 15). Watch Nunavut MP's powerful goodbye message highlighting racism in Canada. CBC News. https://www.cbc.ca/news/politics/parliame nt-farewell-speeches-1.6067283

Wolfe, P. (2006). Settler colonialism and the elimination of the native. Journal of Genocide Research, 8(4). doi: 10.1080/14623520601056240 